\title{
Perbandingan Hasil Belajar Siswa antara Model Kooperatif NHT dengan Model Konvensional pada Mata Pelajaran PAI
}

\author{
Hadi Rusadi ${ }^{1}$, Nur Inayah Syar' ${ }^{2}$, Abdul Qodir $^{3}$ \\ 1,2,3 IAIN Palangkaraya
}

Email: hrusadi7@gmail.com

\begin{abstract}
ABSTRAK
Penelitian ini bertujuan untuk mengetahui hasil belajar siswa setelah diterapkan model pembelajaran NHT pada pembelajaran PAI, hasil belajar siswa setelah diterapkan model pembelajaran konvensional pada pembelajaran PAI, dan perbedaan hasil belajar siswa antara penerapan model pembelajaran kooperatif tipe NHT dengan model pembelajaran konvensional. Penelitian ini menggunakan pendekatan kuantitatif jenis quasi eksperimen. Teknik penentuan sampel adalah purposive sampling dengan jumlah 30 siswa. Instrumen penelitian adalah tes hasil belajar dengan jumlah 30 butir soal. Analisis data menggunakan analisis deskriptif serta uji t sampel independen. Hasil penelitian menunjukkan bahwa hasil belajar siswa setelah diterapkan model pembelajaran NHT terdapat $80 \%$ siswa tuntas dan $20 \%$ siswa tidak tuntas dengan perolehan nilai rata-rata kelas 71,8 , hasil belajar siswa setelah diterapkan model pembelajaran konvensional terdapat $73,3 \%$ siswa tuntas dan 26,6\% siswa tidak tuntas dengan perolehan nilai rata-rata kelas 65,3 selain itu tidak terdapat perbedaan hasil belajar siswa yang signifikan antara penerapan model pembelajaran kooperatif tipe NHT dengan model pembelajaran konvensional pada pembelajaran PAI kelas X. Hal ini ditunjukkan dari output hasil uji t sampel independen diperoleh nilai signifikansi 0,188 $>0,05$ sehingga Ho diterima.
\end{abstract}

Kata Kunci: Model NHT; Model Konvensional; Hasil Belajar Siswa

\section{ABSTRACT}

This study aims to determine student learning outcomes after applying the NHT learning model to Islamic Education learning, student learning outcomes after being applied to conventional learning models in Islamic Education learning and the differences in student learning outcomes between the application of the NHT type cooperative learning model with conventional learning models. his study uses a quantitative approach with a quasi-experimental type. The sampling technique was purposive sampling with a total of 30 students. The research instrument was a test of learning outcomes with a total of 30 items. Data analysis used descriptive analysis and independent sample t test. The results showed that the student learning outcomes after applying the NHT learning model there were $80 \%$ of students complete and $20 \%$ of students incomplete with an average grade score of 71.8 , student learning outcomes after applying the conventional learning model there were $73.3 \%$ of students complete and $26.6 \%$ of students did not complete with the acquisition of a class average score of 65.3 besides that there was no significant difference in student learning outcomes between the application of the NHT type cooperative learning model with the conventional learning model in PAI class $X$ learning. T-test independent sample obtained a significance value of 0.188>0.05 so that Ho is accepted.

Keywords: NHT Model; Conventional Model; Student Learning

(C) 2021 Hadi Rusadi, Nur Inayah Syar, Abdul Qodir

Under the license CC BY-SA 4.0

Pedagogika.fip@ung.ac.id P-ISSN: 2086-4469 E-ISSN: 2716-0580 


\section{PENDAHULUAN}

Faktor kemajuan suatu bangsa dalah satunya ditentukan oleh bidang pendidikan. Pendidikan dapat menciptakan manusia yang berpengetahuan, cakap, terampil dan berbudi pekerti luhur. Pada akhirnya dapat meningkatkan kualitas sumber daya manusia, dalam rangka menunjang pelaksanaan pembangunan bangsa dan negara menuju ke arah yang lebih baik.

Bidang pendidikan seharusnya dijadikan jalan utama serta diselenggarakan dengan bijaksana, dan tidak bisa diabaikan oleh setiap orang, hanya melalui pendidikan seseorang dapat diarahkan untuk menjadi manusia yang berkualitas dalam hidupnya. Hal ini sesuai dengan fungsi dan tujuan Pendidikan Nasional yang tercantum dalam UU RI No. 20 tahun 2003.

Tujuan pendidikan nasional yakni menjadikan generasi yang beriman, berakhlak mulia, sehat, berilmu, cakap, kreatif, mandiri, dan menjadi warga negara yang demokratis serta bertanggung jawab. Sepatutnya dalam proses pembelajaran yang dilakukan di kelas harus dilakukan dengan efektif dan efisien sehingga dapat mencapai tujuan pembelajaran. Pendidikan Agama Islam merupakan salah satu mata pelajaran yang berperan penting mengembangkan potensi peserta didik agar menjadi generasi yang sesuai dengan tujuan pendidikan nasional. Tercapainya tujuan tersebut tidak lepas dari peran seorang guru sebagai seorang pendidik.

Guru memegang peranan penting terhadap keberhasilan pembelajaran. Sehingga keberadaan guru yang profesional menjadi salah satu kompetensi. Oleh karena itu, menurut Joni dalam Susanto (2016:133) guru profesional harus memiliki empat kompetensi dasar, yaitu: kompetensi kepribadian, pedagogis, sosial, dan profesional. Seluruh kompetensi profesi yang dituntut dari seorang guru, sematamata untuk meningkatkan kualitas pembelajaran yang pada akhirnya dapat dinilai dari proses dan hasil belajar.

Secara sederhana, yang dimaksud dengan hasil belajar adalah kemampuan yang diperoleh anak setelah melalui kegiatan belajar. Hasil belajar yang diperoleh sangat menentukan kualitas dari mutu pembelajaran yang diterapkan di suatu lembaga pendidikan. Ada banyak faktor yang mempengaruhi, baik faktor internal maupun faktor eksternal. Faktor eksternal yaitu apa yang ada di luar diri peserta didik seperti; keharmonisan keluarga, pergaulan teman, dan juga model pembelajaran yang digunakan guru dalam pembelajaran.

Berbagai model pembelajaran di dalam dunia pendidikan saat ini senantiasa tumbuh bersamaan dengan pertumbuhan 
ilmu serta teknologi. Sehingga keberhasilan pembelajaran tidak lepas dari keahlian guru mengembangkan model- model pembelajaran yang berbasis pada tingginya keterlibatan siswa secara efisien di dalam proses pembelajaran. Pemakaian model yang sesuai akan memunculkan rasa bahagia siswa terhadap pelajaran, meningkatkan motivasi dalam mengerjakan tugas, memberikan kemudahan untuk siswa sehingga dapat menguasai pelajaran sehingga siswa mampu menggapai hasil belajar yang lebih baik (Aunurrahman 2010:143).

Berubahnya paradigma pembelajaran merupakan salah satu pedoman untuk tercapainya proses pembelajaran yang lebih baik. Sehubungan dengan hal tersebut sistem pembelajaran yang semula berpusat pada guru (teacher centered) berubah haluan dengan berpusat pada peserta didik (student centered). Adapun metodologi yang semula dimonopoli oleh ekspositori, berubah menjadi partisipatori. Segala perubahan tersebut bertujuan dalam rangka perbaikan mutu pendidikan, baik dari segi hasil maupun proses pendidikan (Trianto 2007:5).

Proses kegiatan belajar mengajar yang standar biasanya masih menggunakan cara tradisional yaitu didominasi model pembelajaran konvensional. Pada pembelajaran ini suasana kelas cenderung teacher-centered (berpusat pada guru) sehingga siswa menjadi pasif. Namun, siswa yang pasif dapat dipacu untuk terlibat menjadi aktif dengan menggunakan pendekatan model pembelajaran tertentu.

Numbered Head Together (NHT) adalah suatu model pembelajaran yang memanfaatkan pendekatan pembelajaran yang menekankan pada penggunaan struktur tertentu yang didesain untuk mempengaruhi model interaksi siswa. Hal yang dikembangkan oleh Spencer Kagan ini bertujuan sebagai alternatif terhadap struktur kelas tradisional, seperti resitasi di mana guru mengajukan pertanyaan kepada keseluruhan kelas dan siswa mengajukan jawaban setelah mengacungkan tangan atau ditunjuk (Ibrahim 2001:25).

NHT banyak mempunyai keunggulan di antaranya adalah siswa dapat melakukan diskusi dengan sungguhsungguh, siswa yang pandai dapat mengajari temannya dan menjadikan setiap siswa menjadi siap menjawab pertanyaan guru, karena sudah belajar dari temannya yang lain (Ibrahim 2001:31). Keunggulan model tersebut akan berpengaruh pada tingkat keterlibatan siswa dalam pembelajaran. Model pembelajaran kooperatif Tipe NHT juga dapat meningkatkan hasil belajar, aktivitas belajar, motivasi belajar serta 
keterampilan sosil, terlebih jika dipadukan dengan media pembelajaran yang lain (Firmansyah, Mahardika, and Gani, 2017; Diana, 2018; Purnamasari, 2019)

Kagan dalam (Tampubolon 2014:94) berpendapat bahwa model pembelajaran NHT mengandung karakteristik khusus pada pembelajaran secara kelompok dengan adanya penyelesaian tugas dengan saling berbagi pendapat. Masing- masing kelompok harus memastikan bahwa masing anggota memahami dan menguasai tugas. Dengan demikian seluruh siswa mampu memahami dan menguasai tugas, sehingga mereka dapat memahami konsep secara saksama. Model pembelajaran ini mengakomodasi peningkatan frekuensi diskusi antar kelompok, serta memudahkan proses evaluasi.

Pembelajaran kooperatif tipe NHT adalah salah satu tipe dalam model pembelajaran kooperatif yang menitikberatkan pada suatu struktur yang secara khusus didesain untuk mempengaruhi hubungan dan interaksi antar siswa dan pada dasarnya bertujuan untuk meningkatkan penguasaan akademik (Ibrahim, 2001:28). Model belajar mengajar kepala bernomor (numbered heads) ini dikembangkan oleh Spencer Kagan. Model ini memungkinkan siswa untuk memiliki kesempatan saling berbagi pendapat dan menimbang jawaban yang paling tepat. Di samping itu tipe ini juga memotivasi peserta didik untuk mengembangkan sikap saling kerja sama mereka (Anatalie 2008:29).

Pada dasarnya model pembelajaran kooperatif tipe NHT adalah salah satu variasi dari diskusi kelompok. NHT adalah salah satu model pembelajaran yang menekankan pada aktivitas siswa dalam mencari, mengolah, dan mengkomunikasikan pengetahuan yang berasal dari sejumlah sumber untuk dapat dipresentasikan di depan teman-temannya (Rahayu 2006:12).

Berdasarkan penjelasan di atas dapat ditarik kesimpulan bahwa model pembelajaran kooperatif tipe NHT merupakan model pembelajaran lebih memberikan penekanan agar siswa terlibat aktif khususnya dalam menganalisis bahan yang terkandung dalam suatu pelajaran dan mengecek pengetahuan peserta didik terhadap isi pelajaran tersebut.

Model pembelajaran kooperatif tipe NHT mempunyai beberapa tujuan dalam penerapannya. Menurut (Ibrahim 2001:28), terdapat tiga tujuan yang seharusnya dapat dicapai dalam pembelajaran kooperatif dengan tipe NHT yaitu hasil belajar akademik struktural: memiliki tujuan untuk meningkatkan kinerja peserta didik dalam berbagai akademik; kesadaran akan adanya 
keragaman: bertujuan agar peserta didik dapat menerima keadaan teman mereka yang memiliki sejumlah perbedaan latar belakang; mengembangkan keterampilan sosial: bertujuan untuk mengembangkan keterampilan sosial siswa.

Berdasarkan hasil wawancara dengan guru mata pelajaran PAI yang berinisial ZK di SMK Negeri 1 Palangka Raya diperoleh hasil bahwa terjadi sejumlah permasalahan pada pembelajaran. Hal tersebut dapat dilihat dari hasil belajar siswa yang masih belum memuaskan, masih didapatkan nilai siswa yang belum mencapai KKM berkisar antara 40 - 60. Adapun KKM untuk mata pelajaran PAI berdasarkan ketentuan yang diberlakukan oleh sekolah pada saat itu adalah 70. Hal demikian menggambarkan siswa masih mengalami kesulitan belajar. Selain itu, guru hanya menggunakan model pembelajaran konvensional dengan metode ceramah ketika mengajar, pembelajaran yang terkesan monoton hingga berdampak

\section{METODE PENELITIAN}

Penelitian ini menggunakan pendekatan kuantitatif jenis quasi eksperimen yang mempunyai kelompok kontrol dan kelompok eksperimen. Adapun desain dalam penelitian ini adalah non equivalent control group design. Instrumen pada tingkat kesungguhan dan keaktifan belajar siswa yang masih rendah. Seperti; tidak memperhatikan ketika belajar, mencoret-coret buku, mengobrol dengan temannya, main hand phone bahkan sampai ada yang ribut ketika guru menjelaskan. Hal tersebut menggambarkan bahwa siswa merasa jenuh dan kurang menyenangkan ketika pembelajaran berlangsung sehingga ketertarikan siswa untuk terlibat dalam pembelajaran masih rendah.

Adapun tujuan yang ingin dicapai dalam penelitian ini yaitu untuk mengetahui hasil belajar siswa setelah diterapkan model pembelajaran kooperatif tipe Numbered Head Together (NHT) pada pembelajaran PAI, hasil belajar siswa setelah diterapkan model pembelajaran, mengetahui perbedaan hasil belajar siswa yang signifikan antara penerapan model pembelajaran kooperatif tipe Numbered Head Together (NHT) dengan model pembelajaran konvensional pada pembelajaran PAI.

penelitian yang digunakan adalah tes hasil belajar berjumlah 30 soal yang telah valid dan reliabel. Teknik penentuan sampel adalah purposive samping pada dua kelas yang terpilih dengan jumlah 15 siswa pada masing-masing kelas. Analisis data menggunakan rumus uji $\mathrm{t}$ sampel independen dengan uji pra syarat uji 
normalitas dan uji homogenitas. Teknik analisis data menggunakan analisis deskriptif dan inferensial.

Analisis inferensial berupa uji $\mathrm{T}$ dua sampel yang digunakan untuk menganalisis perbedaan hasil belajar antara kedua kelompok. Sebelumnya data telah diuji dan terbukti normal serta homogen. Menurut Riduan (2016:213) uji t dua sampel dilakukan untuk membandingkan dua jenis kelompok data, dalam hal ini yaitu kelompok kontrol dan kelompok eksperimen.

\section{HASIL DAN PEMBAHASAN}

\section{HASIL PENELITIAN}

Hasil Belajar Siswa pada Kelas

\section{Eksperimen}

Berdasarkan hasil post test yang telah dilakukan, pengelompokkan hasil belajar siswa pada materi sumber hukum Islam dapat dilihat pada tabel 1 .

Tabel 1 Distribusi Frekuensi Nilai Post Test Kelas Eksperimen

\begin{tabular}{lllll}
\hline No & Nilai Angka & Frekuensi & F (\%) & Krite ria \\
\hline $\mathbf{1}$ & $>60$ & 12 & $80 \%$ & Tuntas \\
\hline $\mathbf{2}$ & $<60$ & 3 & $20 \%$ & Tidak Tuntas \\
\hline
\end{tabular}

Berdasarkan tabel 1, dari 30 butir soal yang telah dijawab oleh 15 orang siswa diketahui bahwa persentase siswa yang tuntas adalah $80 \%$ dan $20 \%$ siswa tidak tuntas. Hal ini menunjukkan bahwa kebanyakan siswa berada pada nilai yang tuntas yaitu sebanyak 12 orang dari 15 siswa. Pada hasil post test, hasil belajar siswa mengalami peningkatan dari hasil pre test yang dapat dilihat pada tabel 2 .

Tabel 2 Distribusi Frekuensi Nilai Pre Test Kelas Eksperimen

\begin{tabular}{lllll}
\hline No & Nilai Angka & Frekuensi & F (\%) & Kriteria \\
\hline $\mathbf{1}$ & $>60$ & 3 & $20 \%$ & Tuntas \\
\hline $\mathbf{2}$ & $<60$ & 12 & $80 \%$ & Tidak Tuntas \\
\hline
\end{tabular}

Berdasarkan tabel 2, dari 30 butir soal yang telah dijawab oleh 15 orang siswa diketahui bahwa persentase siswa yang tuntas adalah $20 \%$ dan $80 \%$ siswa tidak tuntas. Hal ini menunjukkan bahwa siswa yang berada pada nilai yang tuntas yaitu 3 orang dari 15 siswa.
Dengan demikian pada pre test ini, jumlah siswa yang tidak tuntas lebih banyak jika dibandingkan dengan pada saat post test.

\section{Hasil Belajar Siswa pada Kelas Kontrol}

Berdasarkan hasil post test yang telah dilakukan, pengelompokkan hasil

\section{Pedagogika.fip@ung.ac.id P-ISSN: 2086-4469Ｅ-ISSN: 2716-0580}


belajar siswa pada materi sumber hukum Islam dapat dilihat pada tabel 3 . Tabel 3 Distribusi Frekuensi Nilai Post Test Kelas Kontrol

\begin{tabular}{lllll}
\hline No & Nilai Angka & Frekuensi & F (\%) & Kriteria \\
\hline $\mathbf{1}$ & $>60$ & 11 & $73,3 \%$ & Tuntas \\
\hline $\mathbf{2}$ & $<60$ & 4 & $26,6 \%$ & Tidak Tuntas \\
\hline
\end{tabular}

Berdasarkan tabel 3, dari 30 butir soal yang telah dijawab oleh 15 orang siswa diketahui bahwa persentase siswa yang tuntas adalah $73,3 \%$ dan $26,6 \%$ siswa tidak tuntas. Hal ini menunjukkan bahwa kebanyakan siswa berada pada nilai yang tuntas yaitu sebanyak 11 orang dari 15 siswa. Pada hasil post test, hasil belajar siswa mengalami peningkatan dari hasil pre test yang dapat dilihat pada tabel 4.

Tabel 4 Distribusi Frekuensi Nilai Pre Test Kelas Kontrol

\begin{tabular}{lllll}
\hline No & Nilai Angka & Frekuensi & F (\%) & Kriteria \\
\hline $\mathbf{1}$ & $>60$ & 4 & $26,6 \%$ & Tuntas \\
\hline $\mathbf{2}$ & $<60$ & 11 & $73,3 \%$ & Tidak Tuntas \\
\hline
\end{tabular}

Berdasarkan tabel 4, dari 30 butir soal yang telah dijawab oleh 15 orang siswa diketahui bahwa persentase siswa yang tuntas adalah $26,6 \%$ dan $73,3 \%$ siswa tidak tuntas. Hal ini menunjukkan bahwa siswa yang berada pada nilai yang tuntas yaitu 4 orang dari 15 siswa. Dengan demikian pada pre test ini, jumlah siswa yang tidak tuntas lebih banyak jika dibandingkan dengan pada saat post test.

Perbedaan Hasil Belajar Siswa antara Kelas Eksperimen dan Kelas Kontrol

\section{a. Hasil Uji Normalitas}

Hasil uji normalitas menggunakan SPSS 20 pada hasil belajar siswa dengan materi sumber hukum Islam ditampilkan pada tabel 5 dan tabel 6 .

Tabel 5 Hasil Uji Normalitas Kelas Eksperimen (X DPIB)

\begin{tabular}{lcccccc}
\hline & \multicolumn{2}{c}{ Kolmogorov-Smirnov } & \multicolumn{3}{c}{ Shapiro-Wilk } \\
\cline { 2 - 6 } & Statistic & $\mathrm{df}$ & Sig. & Statistic & $\mathrm{df}$ & Sig. \\
\hline Pretest Kelas X DPIB & 0,124 & 15 & $0,200^{*}$ & 0,951 & 15 & 0,540 \\
\hline Posttest Kelas X DPIB & 0,153 & 15 & $0,200^{*}$ & 0,943 & 15 & 0,425 \\
\hline
\end{tabular}

Berdasarkan hasil olah data pada program test kelas eksperimen menggunakan uji SPSS, untuk pengujian normalitas hasil pre Shapiro Wilk dengan nilai signifikansi 
PEDAGOGIKA

Volume 12 (Nomor 2) 2021

HaL. 161-175

0,540. Sedangkan untuk pengujian signifikansi 0,425. Artinya kedua data normalitas hasil post test kelas eksperimen tersebut berdistribusi normal karena nilai menggunakan uji Shapiro Wilk dengan nilai signifikansi >0,05.

Tabel 6 Hasil Uji Normalitas Kelas Kontrol (X BKP)

\begin{tabular}{ccccccc}
\hline & \multicolumn{2}{c}{ Kolmogorov-Smirnova } & \multicolumn{3}{c}{ Shapiro-Wilk } \\
\cline { 2 - 7 } & Statistic & df & Sig. & Statistic & df & Sig. \\
\hline Pretest Kelas X BKP & 0,125 & 15 & $0,200^{*}$ & 0,973 & 15 & 0,905 \\
\hline Posttest Kelas X BKP & 0,182 & 15 & $0,194^{*}$ & 0,925 & 15 & 0,230 \\
\hline
\end{tabular}

Berdasarkan hasil olah data pada program SPSS, untuk pengujian normalitas hasil pre test kelas kontrol menggunakan uji Shapiro Wilk dengan nilai signifikansi 0,905. Sedangkan untuk pengujian normalitas hasil post test kelas kontrol menggunakan uji Shapiro Wilk dengan nilai signifikansi 0,230. Artinya kedua data tersebut berdistribusi normal karena nilai signifikansi $>0,05$.

\section{b. Uji Homogenitas}

Berdasarkan data hasil tes hasil belajar siswa pada materi sumber hukum Islam diketahui bahwa data berdistribusi normal, maka langkah selanjutnya dilakukan uji homogenitas. Untuk menguji homogenitas hasil tes tersebut dilakukan dengan menggunakan bantuan SPSS 20 dengan taraf signifikansi $=5 \%$ atau taraf kepercayaan 95 $\%$. Hasil uji homogenitas menggunakan uji Levene pada kelas eksperimen dapat dilihat pada 7.

Tabel 7 Hasil Uji Homogenitas Kelas Eksperimen (X DPIB)

\begin{tabular}{|c|c|c|c|}
\hline Lavene Statistic & df1 & df2 & Sig. \\
\hline 0,823 & 1 & 28 & 0,372 \\
\hline
\end{tabular}

Berdasarkan tabel 7 diketahui bahwa nilai memiliki varian data yang sama. Sementara signifikansi $=0,372>0,05$. Hal ini berarti hasil uji homogenitas menggunakan uji kedua data yaitu pre test dan post test pada Levene pada kelas kontrol dapat dilihat pada kelas eksperimen adalah homogen atau tabel 8.

Tabel 8 Hasil Uji Homogenitas Kelas Kontrol (X BKP)

\begin{tabular}{|c|c|c|c|}
\hline Lavene Statistic & df1 & df2 & Sig. \\
\hline 0,001 & 1 & 28 & 0,971 \\
\hline
\end{tabular}

Pedagogika.fip@ung.ac.id P-ISSN: 2086-4469 E-ISSN: 2716-0580 
PEDAGOGIKA

Volume 12 (Nomor 2) 2021

HaL. 161-175

Berdasarkan tabel 8 diketahui bahwa nilai Hasil belajar yang dibandingkan dalam signifikansi $=0,971>0,05$. Hal ini berarti kedua data yaitu pre test dan post test pada kelas kontrol adalah homogen atau memiliki varian data yang sama.

c. Hasil Uji-T Dua Sampel Independen penelitian ini adalah hasil belajar siswa setelah melaksanakan pre test dan post test. Berdasarkan hasil pre test dan post test yang telah dilakukan pada dua kelas yang berbeda, maka hasil belajar siswa ditampilkan pada tabel 9.

Tabel 9 Distribusi Hasil Belajar Kelas Eksperimen dan Kontrol

\begin{tabular}{cccccc}
\hline \multirow{2}{*}{ No } & Kelas & \multicolumn{2}{c}{ Persentase Tuntas } & \multicolumn{2}{c}{ Persetase Tidak Tuntas } \\
\cline { 3 - 6 } & & Pre test & Post test & Pre test & Post test \\
\hline $\mathbf{1}$ & Kelas X DPIB & 20 & 80 & 80 & 20 \\
\hline $\mathbf{2}$ & Kelas X BKP & 26,6 & 73,3 & 73,3 & 26,6 \\
\hline
\end{tabular}

Berdasarkan tabel 9, diketahui hasil pre test menunjukkan bahwa $20 \%$ siswa kelas X-DPIB dan 26,6\% siswa kelas XBKP mendapatkan hasil belajar yang tuntas. Adapun hasil post test menunjukkan bahwa ada peningkatan hasil belajar yang signifikan dengan persentase $80 \%$ siswa kelas X-DPIB dan 73,3\% siswa kelas $\mathrm{X}$ BKP mendapatkan hasil belajar yang tuntas.
Meskipun hasil belajar siswa antara kelas ekperimen dengan kelas kontrol samasama mengalami peningkatan, akan tetapi tingkat keberhasilan dua kelas tersebut memiliki perbedaan. Hal ini bisa dibuktikan dengan melihat distribusi pencapaian hasil belajar pada Gambar 1.

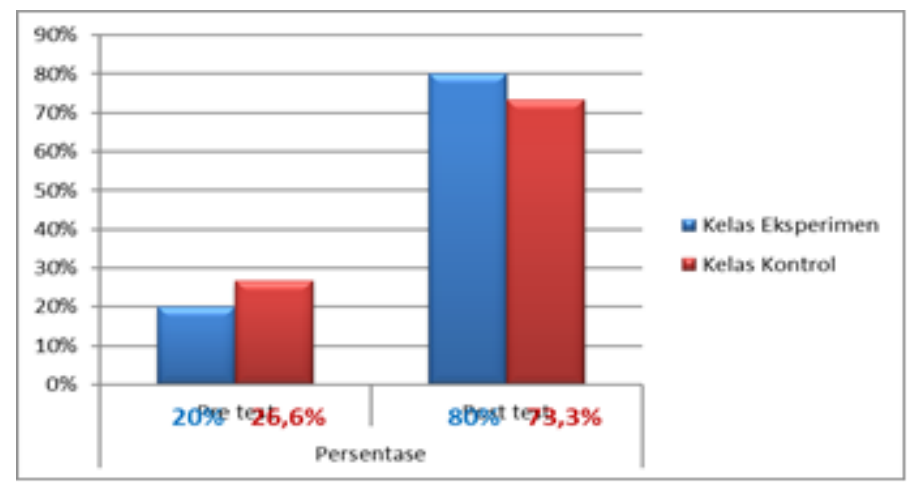

Gambar 1 Distribusi Pencapaian Hasil Belajar Tuntas Kelas Eksperimen dan Kontrol 
Berdasarkan gambar 1 perolehan hasil belajar di atas, diketahui kenaikan hasil belajar tuntas kelompok eksperimen lebih besar daripada kelas kontrol. Kenaikan hasil belajar tuntas dari pre test ke post test pada kelas kontrol sebesar 46,7\%. Sedangkan kelas eksperimen sebesar $60 \%$ sehingga diketahui kenaikan hasil belajar tuntas kelas eksperimen lebih besar 13,3\% dibandingkan dengan kelas kontrol.

Hal tersebut di atas juga bisa dibuktikan dengan melihat kenaikan nilai rata-rata hasil belajar kelas dari pre test ke post test. Pada hasil post test kelas eksperimen diketahui nilai rata-rata 71,8 dari 46,8 pada hasil pre test dengan kenaikan nilai 25. Sedangkan hasil post test kelas kontrol diketahui nilai rata-rata 65,3 dari 48,6 pada hasil pre test dengan kenaikan nilai 16,7. Hal ini menunjukkan bahwa kenaikan rata-rata hasil belajar kelas eksperimen lebih besar dibandingkan dengan kelas kontrol. Uji analisis yang digunakan untuk menjawab hipotesis penelitian ini adalah uji $\mathrm{T}$ sampel independen. Hal ini karena penulis menggunakan dua kelas yaitu kelas eksperimen dan kelas kontrol yang diberikan pre test dan post test untuk membandingkan hasil belajar siswa setelah diterapkan model pembelajaran NHT pada kelas eksperimen dan model pembelajaran konvensional pada kelas kontrol. Penulis menggunakan program SPSS 20 untuk menguji hipotesis. Hasil uji hipotesis untuk data hasil belajar siswa pada materi sumber hukum Islam ditampilkan pada tabel 10 .

Tabel 10 Hasil Uji T Sampel Independen Group Statistic

\begin{tabular}{cccccc}
\hline Kelas & N & Mean & Std. Deviation & Std. Error Mean \\
\hline \multirow{2}{*}{ Nilai } & Kelas X DPIB & 15 & 71,80 & 13,289 & 3,431 \\
\hline \multirow{2}{*}{ Kelas X BKP } & 15 & 65,33 & 12,938 & 3,340 \\
\hline
\end{tabular}

Berdasarkan tabel 10 nilai signifikansi hasil belajar siswa yang signifikan antara adalah 0,188. Hal ini menunjukkan bahwa penerapan model pembelajaran kooperatif nilai signifikansi >0,05. Maka keputusan tipe NHT dengan model pembelajaran yang diambil dari hasil uji ini adalah $\mathrm{H}_{\mathrm{o}}$ konvensional pada pembelajaran PAI kelas diterima dan $\mathrm{H}_{\mathrm{a}}$ ditolak. Sehingga dapat $\mathrm{X}$ di SMK Negeri 1 Palangka Raya. disimpulkan bahwa tidak terdapat perbedaan

\section{PEMBAHASAN}

\section{Hasil Belajar Kelas Eksperimen}

Ada berbagai macam model atau metode yang digunakan seorang guru dalam 
pembelajaran. Salah satunya adalah model pembelajaran NHT. Model ini berupaya untuk membuat siswa menjadi lebih aktif dalam belajar sehingga dampak dari keaktifan siswa tersebut dapat meningkatkan hasil belajar.

Berdasarkan perolehan hasil belajar siswa terlihat bahwa seluruh siswa mengalami peningkatan hasil tes dari pre test dan post test. Persentase siswa yang hasil belajarnya meningkat dari pre test dan post test yaitu sebesar $100 \%$. Hal ini menunjukkan bahwa semua siswa pada kelas eksperimen mengalami peningkatan hasil belajar yang sangat baik setelah diberikan model pembelajaran NHT. Hal ini juga sesuai dengan kelebihan yang dimiliki model pembelajaran NHT, menurut Ibrahim (2001:31) salah satunya menjadikan setiap siswa menjadi siap semua dan bersungguhsungguh mengikuti kegiatan pembelajaran sehingga berdampak pada hasil belajar yang maksimal.

Mulyana et al. (2016:339) menjelaskan bahwa model pembelajaran NHT mampu meningkatkan hasil belajar siswa pada materi kenampakan alam dan sosial budaya. Hal ini menunjukkan bahwa

\section{Hasil Belajar Kelas Kontrol}

Hasil belajar dari kelas kontrol merupakan hasil belajar yang diperoleh dari penerapan model pembelajaran model ini sangat cocok untuk diterapkan guna meningkatkan hasil belajar siswa. Beberapa faktor penyebab peningkatan tersebut yaitu komunikasi siswa, tanggung jawab siswa, dan kerja sama siswa dengan kriteria penilaian baik sekali. Sama halnya dalam penelitian siswa belajar dengan serius, rasa senang serta mengikuti kegiatan pembelajaran sebagaimana mestinya sehingga berdampak pada hasil belajar yang meningkat.

Selain itu Sulfiani (2016:6) menjelaskan bahwa model pembelajaran NHT juga mampu meningkatkan aktivitas belajar siswa kelas XI SMA. Hal ini juga menunjukkan bahwa selain meningkatkan hasil belajar, model ini juga cocok untuk diterapkan guna meningkatkan aktivitas belajar siswa. Salah satu faktor penyebab berhasilnya penelitian yang dilakukan tersebut yaitu kemampuan guru dalam mengelola pembelajaran dengan kriteria penilaian baik. Hal ini sesuai dengan kelebihan model pembelajaran NHT, menurut Ibrahim (2001:31) salah satunya menumbuh kembangkan kedisiplinan, minat, kerja sama, keaktifan dan tanggung jawab.

konvensional. Berdasarkan perolehan hasil belajar siswa terlihat bahwa seluruh siswa mengalami peningkatan hasil tes dari pre test dan post test. Persentase siswa yang 
hasil belajarnya meningkat dari pre test dan post test yaitu sebesar $100 \%$. Hal ini menunjukkan bahwa semua siswa pada kelas kontrol mengalami peningkatan hasil belajar yang sangat baik setelah diberikan model pembelajaran konvensional.

Menurut Sanjaya dalam Susanti (2015:120) kelebihan model konvensional salah satunya menyampaikan informasi dengan cepat sehingga bagi siswa yang memperhatikan, mendengarkan, dan menanyakan apabila perlu akan dengan mudah memahami materi yang disampaikan sehingga berpengaruh pada peningkatan hasil belajar siswa.

\section{Perbandingan Hasil Belajar antara}

\section{Kelas Eksperimen dan Kelas Kontrol}

Hasil belajar merupakan kemampuan yang dimiliki siswa setelah menerima pengalaman belajar. Adapun dalam penelitian ini kemampuan yang dimaksud yaitu pada aspek pengetahuan siswa. Pengukuran hasil belajar dilakukan dengan menggunakan tes soal yaitu pre test dan post test.

\section{Penelitian dilaksanakan sebanyak} dua kali pertemuan tatap muka pada masingmasing kelas. Pelaksanaan pembelajaran dilakukan pada hari yang sama pada kelas eksperimen dan kelas kontrol. Pertemuan pertama melaksanakan pre test kemudian melaksanakan pembelajaran materi sumber hukum Islam pada subbab Alquran dan hadis yaitu pada tanggal 17 Februari 2020, pertemuan kedua melaksanakan pembelajaran materi sumber hukum Islam pada subbab ijtihad dan hukum takhlifi kemudian melaksanakan post test yaitu pada tanggal 24 Februari 2020.

Alasan peneliti memilih materi sumber hukum Islam selain bertepatan dengan waktu penelitian, peneliti juga ingin mengajak peserta didik untuk selalu berpedoman kepada hukum Islam. Sejatinya dengan berpedoman kepada hukum Islam akan mengantarkan manusia menuju kebahagiaan dunia dan akhirat.

Berdasarkan hasil tes pada kelas eksperimen dan kelas kontrol, siswa mengalami peningkatan hasil belajar. Analisis data menunjukkan bahwa peningkatan hasil belajar siswa pada kelas eksperimen lebih besar dibandingkan dengan kelas kontrol. Meskipun pada analisis data hasil penelitian menunjukkan bahwa tidak terdapat perbedaan hasil belajar yang signifikan antara hasil belajar siswa yang mendapatkan model pembelajaran NHT dengan hasil belajar siswa yang mendapatkan model pembelajaran konvensional. Hal ini dikarenakan pada saat peneliti mewawancarai siswa, mereka merasa senang dan suka terhadap model pembelajaran yang peneliti terapkan. Siswa 
juga memperhatikan saat pembelajaran berlangsung sehingga berdampak pada hasil belajar yang sama-sama meningkat.

Setelah dilakukan pengolahan data diperoleh hasil terdapat perbedaan rata-rata hasil belajar siswa yang menggunakan model pembelajaran NHT dan siswa yang menggunakan model pembelajaran konvensional. Pada siswa yang menggunakan model pembelajaran NHT memperoleh nilai rata-rata yang lebih tinggi dibandingkan nilai rata-rata siswa yang menggunakan model pembelajaran konvensional.

Berdasarkan uji $T$ Sample Independen menggunakan SPSS versi 20 diketahui bahwa nilai signifikansi hasil belajar siswa pada kelas kontrol dan kelas eksperimen adalah $0,188>0,05$ maka dengan demikian $\mathrm{H} 0$ diterima dan $\mathrm{Ha}$ ditolak. Hal ini berarti tidak terdapat perbedaan hasil belajar siswa yang

\section{SIMPULAN}

Berdasarkan hasil penelitian yang telah dilakukan, maka dapat disimpulkan bahwa hasil belajar siswa pada mata pelajaran PAI setelah diterapkan model pembelajaran NHT terdapat $80 \%$ atau 12 siswa tuntas dan $20 \%$ siswa tidak tuntas dengan perolehan nilai rata-rata kelas 71,8 . Hasil belajar siswa pada mata pelajaran PAI setelah diterapkan model pembelajaran signifikan dari penerapan model pembelajaran kooperatif tipe NHT dengan model pembelajaran konvensional pada pembelajaran PAI kelas $\mathrm{X}$ di SMK Negeri 1 Palangka Raya.

Hasil yang diperoleh sejalan dengan penelitian (Akasi, Marcella, and Perdana (2015:52) yang menjelaskan bahwa model pembelajaran NHT tidak berpengaruh terhadap peningkatan hasil belajar siswa. Menurut teori seharusnya pembelajaran di kelas eksperimen lebih berpengaruh dibandingkan kelas kontrol tetapi karena ada faktor yang mempengaruhi yaitu siswa sudah terbiasa dengan model pembelajaran konvensional. Hal ini sesuai dengan hasil observasi awal peneliti bahwa guru hanya menggunakan model pembelajaran konvensional. Pada saat peneliti menerapkan model pembelajaran tersebut bukanlah sesuatu yang asing bagi siswa sehingga siswa mudah dalam menerima pembelajaran. konvensional terdapat $73,3 \%$ siswa tuntas dan $26,6 \%$ siswa tidak tuntas dengan perolehan nilai rata-rata kelas 65,3.

Hasil t-test uji $t$ sampel independen diperoleh nilai signifikansi 0,188>0,05 sehingga Ho diterima. Hasil tersebut menunjukkan bahwa tidak terdapat perbedaan hasil belajar siswa yang signifikan antara penerapan model pembelajaran kooperatif tipe NHT dengan 
model pembelajaran konvensional pada pembelajaran PAI kelas X di SMK Negeri 1

\section{DAFTAR PUSTAKA}

Akasi, Aprianto, Marcella, and Muhammad Iqbal Perdana. 2015. 'Penerapan Model Pembelajaran Number Head Together (NHT) Terhadap Kemampuan Representasi Matematis Siswa Kelas V SD.” Jurnal Edumatica 05(2):48-54. doi: 10.22437/edumatica.v5i02.2929.

Anatalie. 2008. Coopetative Learning: Mempraktikkan Cooperative Learning Di Ruang-Ruang Kelas. Jakarta: Grasindo.

Aunurrahman. 2010. Belajar Dan Pembelajaran. Bandung: Alfabeta.

Firmansyah, Yopie, I. Mahardika, and Abdul Gani. 2017. "Pengaruh Model Pembelajaran Kooperatif Tipe NHT (Numbered Head Together) Berbantuan Media Simulasi PheT Terhadap Aktivitas Belajar Dan Hasil Belajar Siswa SMA Di Jember." Jurnal Pembelajaran Fisika Universitas Jember 6(1):97-102.

Hardianty, H. 2016. "Perbandingan Model Pembelajaran Kooperatif Tipe Treffinger Dengan Model Konvensional (Ceramah) Terhadap Hasil Belajar Siswa Kelas XI IPA SMA Negeri 1 Labakkang Pada Materi Sistem Pernapasan Manusia." Universitas Islam Negeri Alauddin Makassar.

Hidayat, M. Yusuf, Ina Rosdiana Lesmanawati, and Djohar Maknun. 2014. "Penerapan Model Pembelajaran CORE (Connecting, Organizing, Reflecting, Dan
Palangka

Raya.

Extending) Terhadap Peningkatan Hasil Belajar Siswa Pada Konsep Ekosistem Di Kelas X SMAN 1 Ciwaringin." Scientiae Educatia 3(2):111-24. doi: 10.24235/sc.educatia.v3i2.544.

Ibrahim, Muslim. 2001. Model Pembelajaran Kooperatif. Surabaya: Unesa University Press.

Mauli Diana, Luluk. 2018. Pengaruh Model Kooperatif Tipe Numbered Head Together (NHT) Berbantuan Media Video Terhadap Keterampilan Sosial Dan Hasil Belajar Pada Mata Pelajaran IPS Kelas VIII SMP Islam Al-Hidayah Kaliwates Jember. Vol. 3.

Mulyana, MA, N. Hanifah, AK JayadinataJurnal Pena Ilmiah, and Undefined 2016. 2016. "Penerapan Model Kooperatif Tipe Numbered Heads Together (NHT) Untuk Meningkatkan Hasil Belajar Siswa Pada Materi Kenampakan Alam Dan Sosial Budaya." Penerapan Model Kooperatif Tipe Numbered Heads Together (NHT) Untuk Meningkatkan Hasil Belajar Siswa Pada Materi Kenampakan Alam Dan Sosial Budaya 1(1):331-40. doi: 10.23819/pi.v1i1.3039.

Purnamasari, Evi Lia. 2019. "Pengaruh Model Pembelajaran Kooperatif Tipe Numbered Heads Together (NHT) Terhadap Motivasi Belajar Dan Hasil Belajar Peserta Didik Pada Mata Pelajaran Fiqih Kelas VIII Madrasah Tsanawiyah Negeri 7 Tulungagung." IAIN Tulungagung.

Rahayu. 2006. Media Pembelajaran. Jakarta: Raja Grafindo Persada. 
Riduwan. 2016. Dasar-Dasar Statistika. Bandung: Alfabeta.

Sugiyono. 2016. Metode Penelitian Kuantitatif, Kualitatif, Dan $R \& D$. Bandung: Alfabeta.

Sulfiani, Ridha. 2016. 'Penerapan Model Pembelajaran Kooperatif Tipe Numbered Head Together ( NHT ) Untuk Meningkatkan Hasil Belajar Kimia Siswa Kelas XI IPA1 SMA Negeri 3 Watampone ( Studi Pada Materi Pokok Struktur Atom, Sistem Periodik Unsur Dan Bentuk Molekul ) Application." Jurnal Chemica 17(1):1-13.

Susanti, Ita. 2015. "Pengaruh Model Pembelajaran Kooperatif Tipe Number
Head Together (NHT) Terhadap Hasil Belajar Matematika Siswa Kelas VIII Di MTs Muhammadiyah 2 Palembang." UIN Raden Fatah Palembang.

Sundayana, Rostina. 2016. Statistika Penelitian Pendidikan. Bandung: Alfabeta.

Susanto, MP Ahmad. 2016. "Teori Belajar Dan Pembelajaran Di Sekolah Dasar."

Tampubolon, Saur. 2014. Penelitian Tindakan Kelas Sebagai Pengembangan Profesi Pendidik Dan Keilmuan. Jakarta: Erlangga.

Trianto. 2007. Model-Model Pembelajaran Inovatif Berorientasi Kontruktivistik. Jakarta: Prestasi Pustaka. 